\title{
The Lithographic Album 1873: Reproductive Media and Visual Art in the Age of Lithographic Reproduction
}

\author{
Anna Dahlgren
}

\begin{abstract}
This chapter merges media studies with art history or visual studies, as it combines an attentiveness to aesthetics and the materiality of images with an interest in their medium and mediation. It thereby seeks to bridge the alleged gulf between the hermeneutic traditions of art history and the focus on medium and techniques of media studies in general and of media archaeology in particular. As a case study and in focus for the analysis is the Swedish publication Lithographic Album: Portfolio for the Parlour Table, published in Stockholm I 873 . This 2I-page publication includes lithographic reproductions of photographs, oil paintings, and sculptures adjoined by explanatory texts. In focus is how the combination of texts and images convey how the artworks should be interpreted. Moreover, the texts display contrasting understandings of different artistic mediums, how they should be perceived and their ability to advance certain contents. Taken together, it is evident that the Lithographic Album is tinged by a photographic paradigm of truth and immediacy both in the cases where it describes paintings as documents and when it urges the reader to see the artworks with their own eyes.
\end{abstract}

The late eighteen century and early nineteenth century saw a number of new techniques for reproducing images like xylography

How to cite this book chapter:

Dahlgren, Anna. "The Lithographic Album I 873: Reproductive Media and Visual Art in the Age of Lithographic Reproduction." In The Power of the In-Between: Intermediality as a Tool for Aesthetic Analysis and Critical Reflection, edited by Sonya Petersson, Christer Johansson, Magdalena Holdar, and Sara Callahan, 213-237. Stockholm: Stockholm University Press, 2018. DOI: https://doi.org/ıo.I6993/baq.i. License: CC-BY. 
or wood engraving, lithography, steel print, and photography. ${ }^{\mathrm{I}}$ During the following decades there was in turn an immense production of illustrated books, often labeled "albums," which typically collected portraits, views or reproductions of artworks. ${ }^{2}$ The latter, the reproductions of artworks, had a two-part audience at the time. First, they were tools for practicing artists and in art education, where the work of copying old masters was a core feature in the curriculum. ${ }^{3}$ Second, they were aimed at the general public, primarily the bourgeoisie, who sought to educate themselves in the visual art. This chapter considers an example of the latter, the Swedish publication Lithographic Album: Portfolio for the Parlour Table (Litografisk album: Portfölj för salongsbordet) published in Stockholm in I 873 (Figure I). ${ }^{4}$

Lithographic Album comprises twenty-one pages, which includes twelve images and some explanatory text. The images are reproductions of photographs, oil paintings, and sculptures. In total it holds reproductions of three photographs, five oil paintings, three sculptures, and an image of unknown medium. The original images and artworks were contemporary and depicted living celebrities of the period, paintings made by Swedish and Danish artists between 1854 and I 872 , and statues which had recently been produced and stood in Stockholm at the time. Although the title of the publication indicates that it contains lithographs, it may also include wood engravings. In fact, the term "lithography" was extensively used in the nineteenth century and did not always refer to the stone-based printing method, but rather to printed

I The xylographic method/wood engraving was invented by Thomas Bewick in 1777 , lithography by Alois Senefelder in 1798 , steel print by Jacob Perkins in I 820 and photography by several persons in the I 820 s and I 83 os. See for example Gerald W. R. Ward, The Grove Encyclopedia of Materials and Techniques in Art (Oxford: Oxford University Press, 2008), 347-350, 484-485, 78I-782; Jane Turner, ed., The Dictionary of Art, vol. Io (London: MacMillan Publishers Ltd, I996), 394-396; Per Bjurström, Gamla grafiska blad (Västerås: ICA-förlaget, I974).

2 Anna Dahlgren, Ett medium för visuell bildning: Kulturhistoriska perspektiv på fotoalbum I850-I950 (Stockholm: Makadam, 2013).

3 Turner, The Dictionary of Art, vol. 7, 830-83 I.

${ }^{4}$ Litografiskt album: Portfölj för salongsbordet, Stockholm Artistiska Litografiska Anstalt (Stockholm: J. W. Svenssons Boktryckeri, I873). 


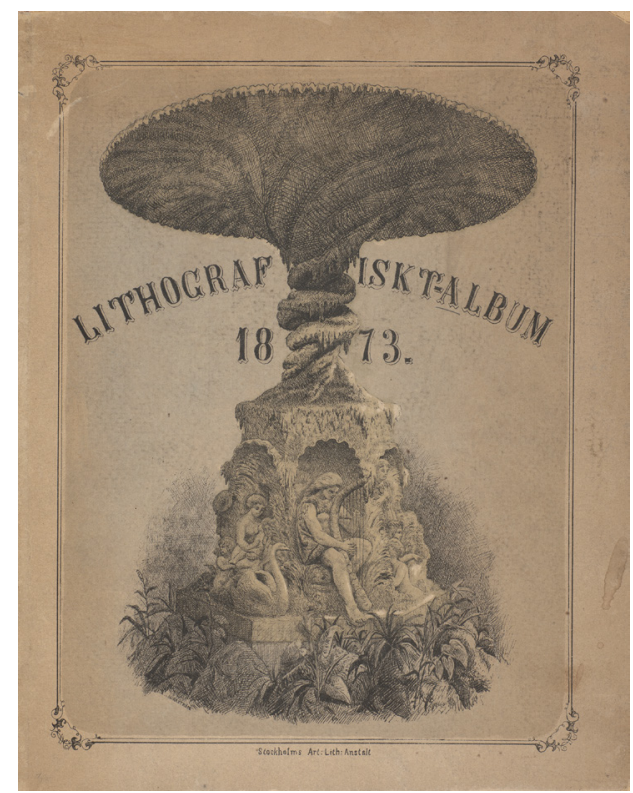

Figure 1. The cover of Lithographic Album, I 873. Reproduction: National Library of Sweden/Kungliga biblioteket, Stockholm. License: CC-BY-NC-ND.

images in general. However lithography was highly popular in the period as is could resemble pen, wash, or crayon drawing as well as engravings. ${ }^{5}$

The Lithographic Album opens with a table of contents, just like a book, where the twelve pictures are listed and labeled. They are:

H. M. The King, H.R.H. Prince August, Earl Grefve von Rosen, The Beggar Boy (with text), Danish soldier (with text), Hjalmar den Hugfulle (with text), the convalescent (with text), Bellman's statue (with text), The fisherman boy (with text), Molin's fountain (with text), Scanian landscape (with text), and Ruin.

5 Lithographic prints are made through drawings on stone while xylographic prints are made through engraving in end wood. The latter rather look like line drawings and are similar to steel print. For an overview of different printing techniques see references in note $\mathrm{I}$. 
Thus eight of the images are adjoined by explanatory text, which follows immediately after the table of contents. The shortest are only one paragraph of six lines, while the most extensive is a just over two full pages long. This is in turn followed by twelve spreads displaying one lithographic print each.

In this chapter, I seek to discuss how the combination of texts and images convey how the images should be interpreted and perceived. Moreover the texts display contrasting understandings of different artistic mediums and their ability to advance certain contents or messages. In the following, I will pay particular attention to the wordings and concepts used to describe how the artworks convey meaning and how they are to be perceived literally and figuratively. It is evident that some images' techniques required extensive explanation while they were superfluous is some cases and even detrimental in others.

\section{Art, Image, and Media Studies}

The present chapter ties into recent developments of images studies, which recognize that "the physical properties of images are as important as their social function." ${ }^{6}$ As such, it is informed by media studies on the one hand, and art history, Bildwissenschaft, and visual studies on the other. It thereby seeks to bridge the alleged gulf between the hermeneutic traditions of art history and the focus on medium/techniques of media studies in general and of media archaeology in particular. It thus combines what Wolfgang Ernst has argued are two incompatible methods: the technological considerations from media archaeology with attentiveness to visual details and aesthetics common to art historical analysis. ${ }^{7}$ The latter includes a consideration of form, colour, image technique, perspective, and content of the images. Accordingly, the following case study includes close formal and content analyses of particu-

${ }^{6}$ Keith Moxey, "Visual Studies and the Iconic Turn," Journal of Visual Culture 7:2 (2008): I3 I-I46, I32.

7 Wolfgang Ernst, "Let There Be Irony: Cultural History and Media Archeology in Parallel Lines," Art History 28:5 (2005): 582-603. 
lar pictures common to art historical studies with a simultaneous consideration of the materiality of the medium and the system in which this mediating apparatuses appear and function, which are common to media studies. By using the word media system, I seek to acknowledge that artefacts like the Lithographic Album act as components in a historically situated system of distribution and circulation of different media, which also then per default have intermedial relations, thus both within itself and in relation to other media. The term media system refers to the networking character of media and acknowledges the relations between the whole media system and its constituted parts. Consequently, this perspective directs the attention to intermedial relations in which technical, social, economic aspects, and I would add aesthetic aspects, are taken into consideration. ${ }^{8}$

The overall aim is to disclose the general implications of acknowledging images as mediated and the further implications of these mediations. Moreover, this combination of media history and art history uncover the entangled history of mass media and art in modernity. As pointed out by Hans Belting, there is a need for a dialogue between art history and media studies because of the "coexistence of art and non-art images even in historical times." 9 As the following analysis will uncover, a media perspective on the art field and an artefact like the Lithographic Album has a number of implications. First, a media perspective acknowledges the multi-modality of this object, being a combination of different media, texts, and lithographic images, which in turn remediate other image media. Thus there are intermedial relations within the album itself and yet also between the album and that which it

${ }^{8}$ Jonas Harvard and Patrik Lundell, eds., I 800-taletsmediesystem (Stockholm: Kungliga biblioteket, 20I0), 7-9. See also Lisa Gitelman and Geoffrey B. Pingree, eds., New Media I740-I9I5 (Cambridge: MIT Press, 2003); Erkki Huhtamo and Jussi Parikka, eds., Media Archaeology: Approaches, Applications and Implications (Berkley: University of California Press, 20I I); Sunil Manghani, Image Studies (London: Routledge, 20I3), 26-27.

9 Hans Belting, Art History after Modernism (Chicago: University of Chicago Press, 2003), I63. 
seeks to represent. ${ }^{\text {.o }}$ Second, the Lithographic Album is a medium in the sense that it is a conveyer for interpersonal information. It has a sender and audience, and in this analysis I will also study how this composite medium addresses its audience.

The present case study is also informed by the notions of mediatization. It is an example of what Jürgen Wilke has defined as the "dissemination of art by secondary media," that is mediation and dissemination of art via mass media. ${ }^{\text {II }}$ Indeed printed books like the album in focus in this chapter could be understood as pre-modern mass media, which assumed the same functions as did later film and television as a conveyer of art to the large public. However, I do not only consider this print media as a neutral conveyor for different cultural contents, but rather this case displays that print media has played a decisive role in the construction of art and the understanding of different artistic mediums, not only through writings on art but in addition also in the way art has been reproduced via printed media. This includes an attentiveness to form, colour, perspective, and content.

Typically writings on the mediatization in society consider the contemporary early twenty-first century, sometimes the period of high modernity but seldom earlier historical periods. ${ }^{\mathrm{I2}}$ It is indeed true that the processes of mediatization are progressive. Yet I argue that media has not only left its mark on the everyday life in high modernity and contemporary times but also in earlier historical periods. If by media convergence we mean "flow of content across multiple media platforms," this has been going on well before the contemporary age of digital dissemination. ${ }^{\mathrm{I}}{ }^{3}$ This is particularly

ז Hans Lund, Intermedialitet: Ord, bild och ton $i$ samspel (Lund: Studentlitteratur, 2002).

I Jürgen Wilke, “Art: Multiplied Mediatization," in Mediatization of Communication, ed. Knut Lundby (Berlin: De Gruyter Mouton, 20 14), $465-482$.

I2 See for example Andreas Hepp, Cultures of Mediatization (Cambridge: Polity, 20I2); Stig Hjarvard, The Mediatization of Culture and Society (London: Routledge, 2013), 6-7; Lundby, ed., Mediatization of Communication.

${ }^{13}$ Henry Jenkins, Convergence Culture: Where Old and New Media Collide (New York: New York University Press, 2006). See also Hepp, Cultures of Mediatization, 26. 
true within the art field where the practices of making replicas, pastiches, and paraphrases has a long tradition. An important starting point for this chapter is thus to acknowledge images as embedded, networked, and mediated. While this is a default stance in scholarly work on imagery of journalism and media, it is not always highlighted in studies on visual art. However, visual art is, and has historically always been, mediated and entangled in media systems, be it the illustrated handbooks of art history, lithographic and photographic reproductions of artworks, or the gallery or museum itself. ${ }^{\mathrm{I}}$ Simultaneously the majority of media-historical studies focuses on text and not images, and accordingly, the present study stands out in its focus on images. ${ }^{\mathrm{I5}}$

\section{Photographs}

The first three images in the Lithographic Album are portraits of the King of Sweden Oscar II (I 829-I907), his brother Prince August (I83I-I873), and Georg von Rosen (I843-I923). The latter is presented as Earl in the table of contents and as a history painter below the image itself. Von Rosen was at the time a member of the Art Academy in Stockholm and was later appointed professor at the Royal Academy of Arts. These three portraits are made from photographic originals, although this is not stated anywhere in the album. The King's portrait was made by the photographers Eurenius \& Quist while Prince August's and Rosen's were made by the photographer Gösta Florman. ${ }^{16}$ This could not only be deduced from the treatment of light and

${ }^{\mathrm{I} 4}$ For examples of such studies, despite they are not presented as "media studies," see Dan Karlholm, Art of Illusion: The Representation of Art History in Nineteenth-century Germany and Beyond (Bern: Peter Lang, 2004); Thomas. W. Gaehtgens and Louis Marchesano, Display and Art History: The Düsseldorf Gallery and Its Catalogue (Los Angeles: Getty Research Institute, 20I I).

is This is for example pointed out by James Mussell, The NineteenthCentury Press in the Digital Age (Basingstoke: Palgrave Macmillan, 20I2), 69-II3. For examples of studies on visual aspects of media see Vanessa R. Schwartz and Jeannene M. Przyblyski, eds., The Nineteenthcentury Visual Culture Reader (New York: Routledge, 2004).

${ }^{16}$ Eurenius \& Quist's and Gösta Florman's photographic portraits are, for 
shadows in the images themselves, but also in how they are combined with text in the printed album. ${ }^{17}$ None of the portraits have any adjoining separate descriptive text, and in none of the cases is the photographer's name written out. The lack of explanatory text might indicate that the portrayed people were already wellknown to the intended audience, and no further information or explanations were necessary. However, this lack of textual information may also indicate how the medium of photography was perceived at the time. While there is no lengthier explanatory text, the images themselves are adjoined by the name of the sitters. The latter's, that is von Rosen's portrait, is adjoined by his name in printed letters. The portraits of the Royals are on the contrary adjoined by their signatures, which consist of their surnames (Figures 2 and 3 ).

To combine reproductions of photographs with the portrayed person's signature was a very common practice in contemporary press and illustrated books in the second half of the nineteenth century. This did obviously enhance the indexicality of the image. Adding one's signature on photographic portraits was also common practice in the period. Obviously this made the "having been there" effect of the photographic image stronger. Just as the light that had touched the body of the portrayed person had touched the photographic plate and print, the hands of the portrayed person had touched the photographic print while signing the picture. Subsequently, when lithographic reproductions of photographic portraits of contemporary celebrities were published in the illustrated press and albums of portraits, they were often adjoined by the sitters' autograph and not their name in printed letters. Indeed this was a visual strategy for enhancing the photographicality of the xylographic or lithographic prints. Yet the lack of textual information on the medium or technique of the original images and the omission of the producers', that is, the photographers', names

example, held in the collection of The National Library of Sweden (Faz and FaI4c) and in the Royal Collection, Bernadottebiblioteket (PR A Kq I).

${ }^{17}$ For an extensive analysis on how the photographic aesthetic influenced the production of portraits in other images techniques see Solfrid Söderlind, Porträttbruk i Sverige I 840-I 865: En funktions- och interaktionsstudie (Stockholm: Carlsson, I993), 237-244. 


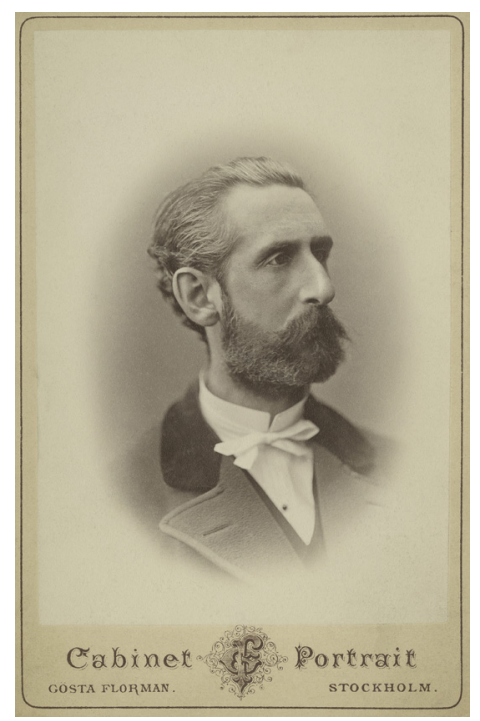

Figure 2. Cabinet portrait of Prince August by Gösta Florman. Photo: Lisa Raihle Rehbäck. Copyright: Swedish Royal Court/Kungl. Hovstaterna, Stockholm. License: CC-BY-NC-ND.

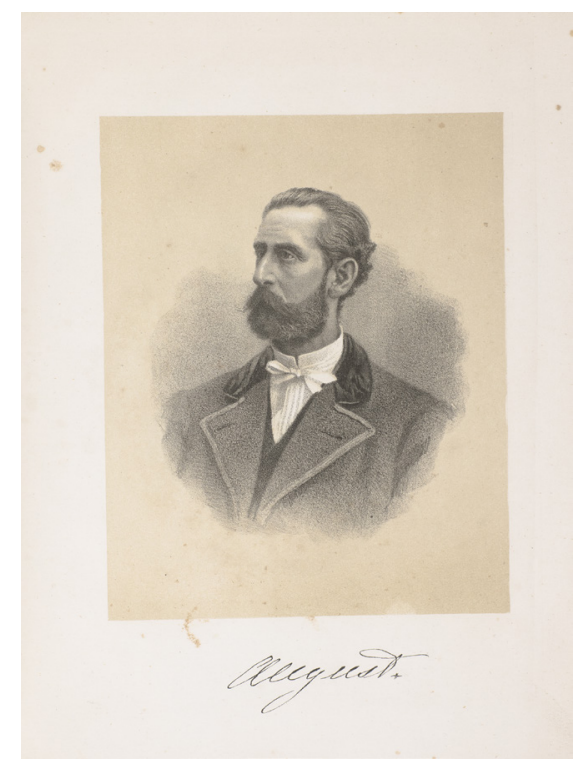

Figure 3. Lithographic reproduction of Florman's photograph of Prince August. Lithographic Album, I 873. Reproduction: National Library of Sweden/Kungliga biblioteket, Stockholm. License: CC-BY-NC-ND. 
may also indicate an understanding of photography as transparent in another sense. These invisibilities emphasize the view that photographs were mechanically produced images without aesthetic considerations and not influenced by the producers', that is, the photographers', personal styles.

\section{Paintings}

The album contains five lithographic reproductions of oil paintings, all of which were produced by Swedish or Danish artists around the mid-nineteenth century. Four of these depict historical or contemporary motifs with edifying content, while one is an image of a rural landscape from the south of Sweden. ${ }^{18}$

Two of the reproduced paintings depict wounded soldiers and in the adjoining text the viewer is encouraged to compare these two images. The full name of the artists and the titles of the paintings are not spelled out in the adjoining text, only the initials and family names of the artists. This might suggest that both artists and these particular paintings were well-known to the intended audience. Hence the reproductions of the artworks that they might already be familiar with through textual sources provided an opportunity to the large public to see the artworks with their own eyes, albeit through a lithographic reproduction. The first painting is presented as Hjalmar the Brave (Hjalmar den Hugfulle) in the table of contents and as Hjalmar's Farewell printed below the lithographic reproduction in the album (Figure 5). This was a large-format oil painting by the Swedish artist Mårten Eskil Winge (г825-г 896) produced in I 866 (Figure 4). The adjoining text points out both its considerable size and image technique by informing the readers

${ }_{18}$ The paintings reproduced in the album were made after Carl Henning Lutzow d'Unker's ( I 828-1866) oil painting The Beggar Boy from I 854 , Mårten Eskil Winge's (I825-1896) Hjalmar's Farewell from I866, Anna Maria Elisabeth Lisinska Jerichau-Baumann's (I8I9-I88I) A Wounded Danish Soldier from I 865, Ferdinand Fagerlin's (I 825-I907) The Convalescence from I867 and an undated Scanian Landscape most probably by Gustaf Rydberg (I835-I933). The album also includes a reproduction of an unidentified image of Berry Pommery Castle in Devonshire, however, only labeled A Ruin. 


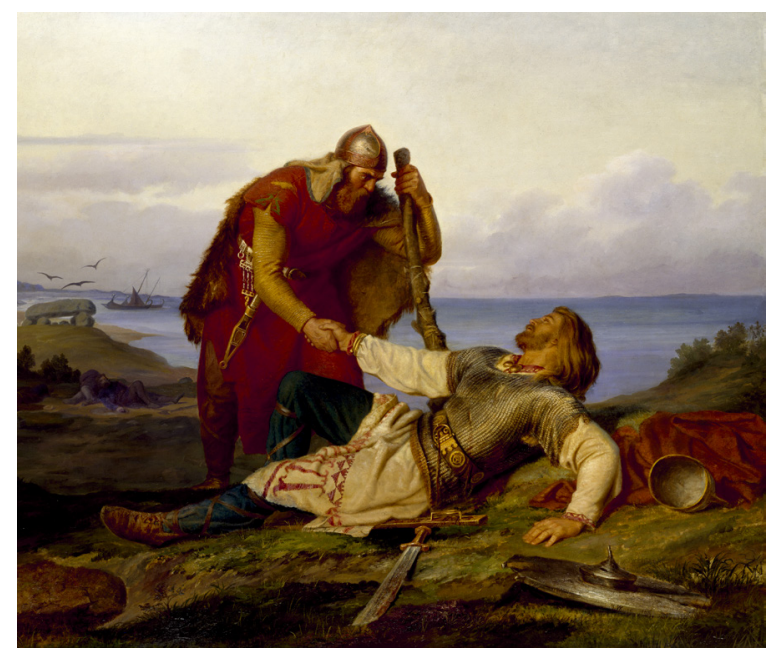

Figure 4. Hjalmar's Farewell. Mårten Eskil Winge, I 866. Oil on canvas. Reproduction and permission: Nationalmuseum/Nationalmuseum, Stockholm. License: CC-PD. Available at Wikimedia Commons: https:// commons.wikimedia.org/wiki/File:Hjalmars_avsked_av_Orvar_Odd_efter_ striden_på_Samsö.jpg.

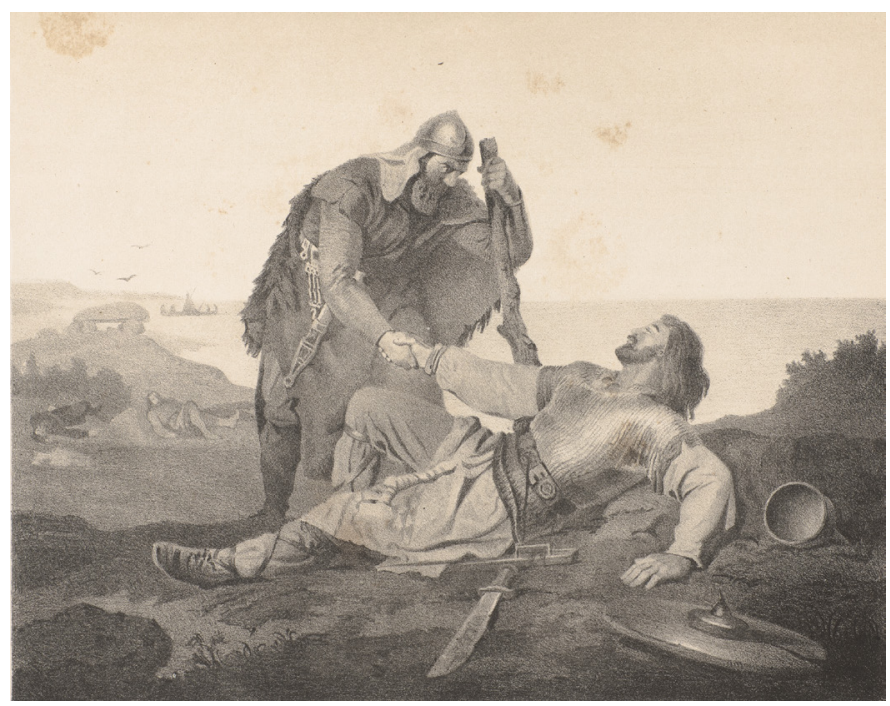

Figure 5. Hjalmar the Brave. Lithographic reproduction of Mårten Eskil Winge's oil painting. Lithographic Album, I 873. Reproduction: National Library of Sweden/Kungliga biblioteket, Stockholm. License: CC-BY-NC-ND. 
that the images have been "taken from Winge's magnificent oil painting." " ${ }^{9}$ At the time of publication, the painting had recently been bequeathed by the former King Carl XV to the Swedish Nationalmuseum, where it is still part of the collection, now catalogued as Hjalmars Farewell to Orvar Odd after the Battle at Samsö. ${ }^{20}$ The painting depicts the ancient Nordic saga where the Viking Hjalmar is dying after a battle. It is the dramatic end of the battle, the death moment of the hero, that is depicted.

In the album, Winge's painting was compared to the painting A Wounded Danish Soldier (En såret dansk kriger) by the Polish-Danish artist Anna Maria Elisabeth Lisinska JerichauBaumann (I8I9-I88I) from I865 (Figures 6 and 7). At the time of publication it was in the possession of the National Gallery of Denmark. ${ }^{21}$ This painting is said to depict a wounded soldier from the nineteenth century. In contrast to the first, the second painting is clearly displaying human fragility and the physical pains of war. The adjoining text invites the readers to compare the two images. Despite that they depict very different types of soldiers, they are said to portray the pains of war and the love of the nation. Their differences are, according to the text, not so much a question of different artistic styles. Rather they depict very different attitudes and characters of the Ancient Nordic times and the contemporary period. ${ }^{22}$ Accordingly, the soldiers are said to have the same courage and will to fight for the nation, yet in "physical strength" today's men are "inferior," a conclusion that obviously ties into the contemporary vivid debate about the degeneration of the population in the Western, industrialized world. Indeed, these lithographic reproductions of oil paintings induce comparisons. They

\footnotetext{
19 The original text reads: "tagen efter Winges präktiga oljemålning."

${ }^{\circ}$ Nationalmuseum, no. I 248, Hjalmars avsked av Orvar Odd efter striden på Samsö, I $69 \times 208 \mathrm{~cm}$. Oil painting. Donation through testament 1872 by Carl XV.

${ }^{21}$ National Gallery of Denmark/Statens museum for Kunst, En såret dansk kriger, I 865 , I07 $\times$ I $42.5 \mathrm{~cm}$. Oil painting, KMS8 52. Bought by National Gallery in 1866 .

${ }_{22}$ The original text reads: "lätt iaktaga hvilka olika typer af krigare, som icke mycket artisten, som icke mer de olika århundradena, framställa för oss.”
} 


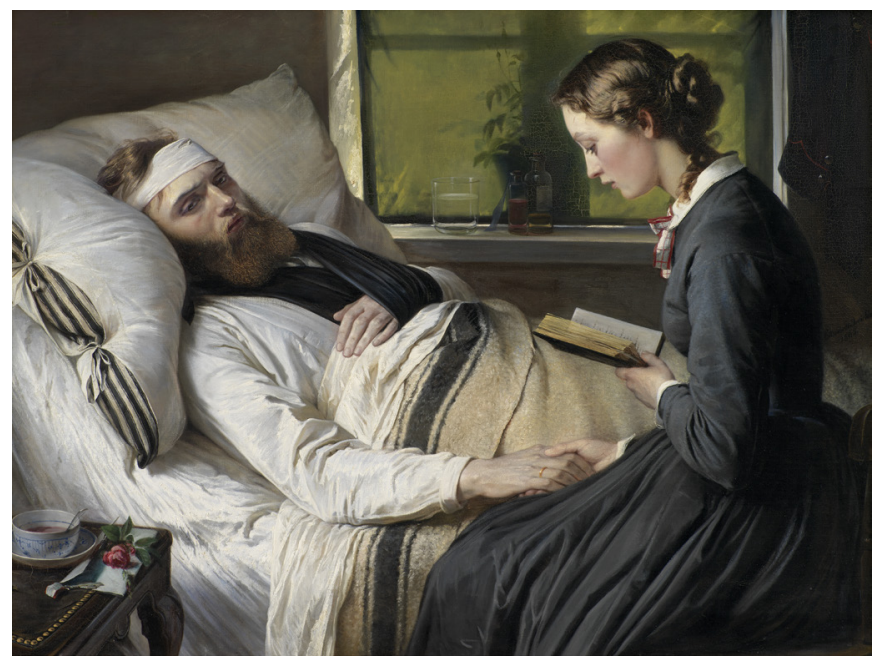

Figure 6. A Wounded Danish Soldier. Maria Elisabeth Lisinska Jerichau-Baumann, I 865. Oil on canvas. Photo and copyright: National Gallery of Denmark/Statens Museum for Kunst, Copenhagen. License: CC-BY-NC-ND.

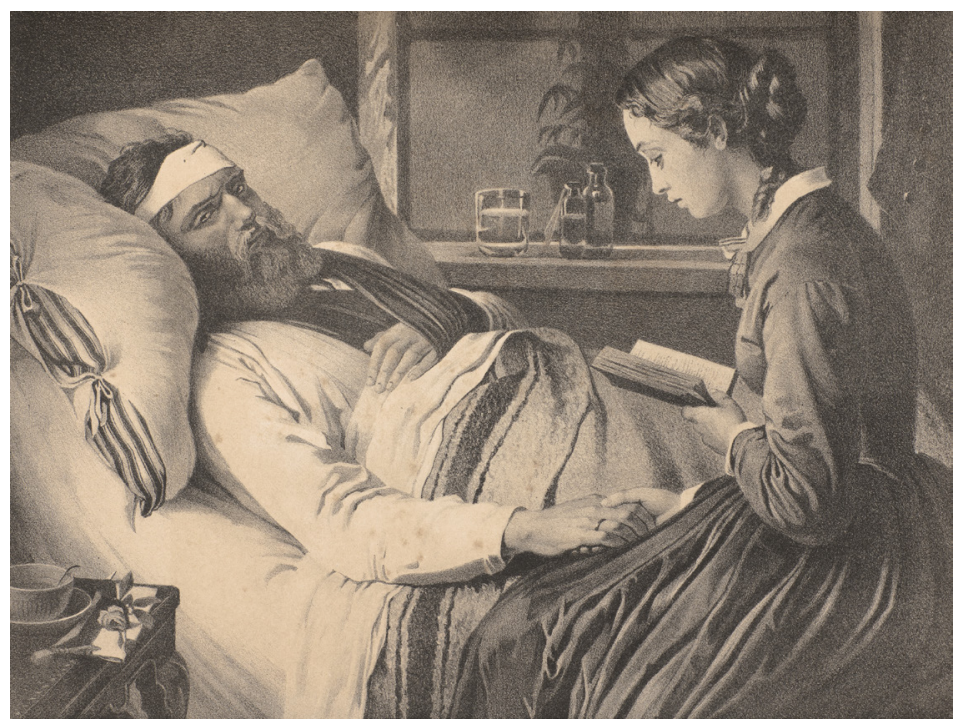

Figure 7. A Wounded Danish Soldier. Lithographic reproduction of Anna Maria Elisabeth Lisinska Jerichau-Baumann's oil painting. Lithographic Album, I873. Reproduction: National Library of Sweden/Kungliga biblioteket, Stockholm. License: CC-BY-NC-ND. 
make the artworks more similar, as they not only transform the images from colour to monochrome, but also make artworks of very different sizes equally large. Thus lithographic reproduction enhances a focus on content before execution, individual artistic style, or periodical style and material features.

A third painting depicts a female convalescent. The picture is not attributed to any artist in the explanatory text or under the image itself. However, the name "Ferd. Fagerlin" and "I 867 " can be discerned faintly in the lithographic reproduction itself. It appears that this is a painting by the Swedish painter Ferdinand Fagerlin (I 825-I907), which was also part of the former King Carl XV's donation to Nationalmuseum in I $872 .{ }^{23}$

Also in this case, the lithographic reproduction is adjoined by a morally edifying text, which points out that "not before we are ill we learn to appreciate the value of health." The picture, however, displays the important turning point "when the strength and hope returns and the convalescent praises God." According to the explanatory text, it is this "solemn moment" that the "artist has so truthfully depicted.” ${ }_{24}$ Thus, just as in Winge's painting, it is the peripeteia, the decisive turning point of the story, or the decisive moment using a photographically charged term, which is being depicted.

Taken together, the texts accompanying the reproduction of these paintings have all a more or less clear moral and edifying function, and they evidently tie into contemporary political and ideological discourses such as nationalism, Christian religiosity, and humility and gratitude for good health and life. The text also focuses on facial expressions, which is typical for the time. Phrenology and physiognomy were well-established sciences in the nineteenth century, and the practice of looking at faces to deduce character, abilities, and intention was common practice in science as well as in popular culture in the 1870 s. $^{25}$ The interest in

${ }_{23}$ Den tillfrisknande, $45 \times 5 \mathrm{I} \mathrm{cm}$, Ferdinand Fagerlin, NM I 204. Donation through testament 1872 by Carl XV.

24 The original text reads: "som artisten så sant tecknat."

25 See for example Peter Hamilton and Roger Hargreaves, The Beautiful and the Damned: The Creation of Identity in Nineteenth Century Photography (London: National Portrait Gallery, 200I). 
or focus on the decisive moments in the depicted oil paintings may also be described as a photographically charged interest typical of the time. For a contemporary viewer, this is particularly conspicuous in the adjoining texts describing images that are not visually of decisive moments, at least not as this visual theme or content has been formulated within the photographic discourse since the twentieth century. ${ }^{26}$

While not spoken, there is an underlying assumption that the oil paintings, reproduced through print, are transparent in the sense that they are not influenced by the artist's personal style or periodical style. On the contrary, these paintings are described as literal windows to the world, both into historical and contemporary periods. Thus there is a strong impetus to perceive the paintings as photographic images in the sense "from life," without any distortions. They are described as authentic or true and as the interpretations made in the text are "easy to observe." The interpretations focus on the emotions of the depicted humans, and as these are clearly displayed visually to its readers, they should in turn experience or ponder the same feelings. ${ }^{27}$ There is an obvious drive to make the paintings "alive," which connects the medium of the illustrated printed album with other contemporary animating techniques like the tableaux vivant, wax cabinets, and museums, which at the time also reproduced popular oil paintings. ${ }^{28}$ The scarcity of information on the artists-in some cases not even their names are spelled out-also emphasizes this will or assumption of transparency.

\section{Statues}

Finally the album includes three lithographic depictions of statues. The first is G. Alfred Nyström's (I 844-I897) statue of the Swedish public poet Carl Michael Bellman (Figure 8).

${ }^{26}$ Henri Cartier-Bresson, The Decisive Moment (New York: Simon and Schuster, I952).

27 See quote in note 22 above.

${ }^{28}$ Hans Medelius, Bengt Nyström, and Elisabet Stavenow-Hidemark, Nordiska museet under I25 àr (Stockholm: Nordiska museets förlag, I998), 277. 
Besides presenting Bellman's life and work in eighteenth-century Stockholm, the explanatory text largely dwells on the prehistory and installation of the statue at Djurgården in outskirts of the capital. Not only are the readers informed that the statue was unveiled on August 16, I872, they also learn that the artist is a pupil of professor Molin and that the pedestal is made with "much taste and care" by the stonecutter Lemon after a design by architect Åbom. ${ }^{29}$ In this paragraph as in the others on paintings and sculptures, the majority of the artists are presented only with their family name, which might indicate that they were well-known to the audience.

While the presentation of the Bellman statue rendered a full page of explanatory text, the second statue depicted is briefly described in one paragraph. It is said to be a Neapolitan fisher boy (Neapolitansk fiskargosse) made by Carl Gustaf Qvarnström (I 8 IO-I 867). According to the text, the statue portrays the young man when he contentedly has finished his fishing and "with his eyes to the sky, through a cheerful song, expresses the vivacious feelings of his heart." ${ }^{\circ}$ The statue in question was produced in marble in 1852 and was bought and hence part of the collection at the Nationalmuseum since I 860 . Parian versions of the statue were in production between I 868 and I925 at the porcelain factory Gustavsberg AB in Sweden. Thus this particular statue appears to have been widely circulated and highly appreciated by the large public in decades to come. ${ }^{3 \mathrm{I}}$

The third statue depicted in lithographic print in the album is only presented as "Molin's fountain" in the table of contents (Figure 9). There is no text beside the lithographic print, and the short explanatory text in the beginning of the album does not give any contextual information on the artist and the artwork. This appears to be the masterpiece of the album as it also adorns the

\footnotetext{
29 This refers to the architect Johan Fredrik Åbom ( I 8 I 7-I 900), artist Johan Peter Molin (I8I4-I873), and stonecutter F. A. Lemon in Stockholm.

30 The original text reads: "med blicken emot höjden, utrycker han i en munter sång, sitt hjertas lefnadsfriska känslor.”

${ }^{3}$ Both the original and an example of the mass-produced parian versions are today part of the collection at Nationalmuseum. NMSk 397. Marble, height I03 cm; NMGu 24063. Parian, $49.5 \times 34.5 \times 26.5 \mathrm{~cm}$.
} 


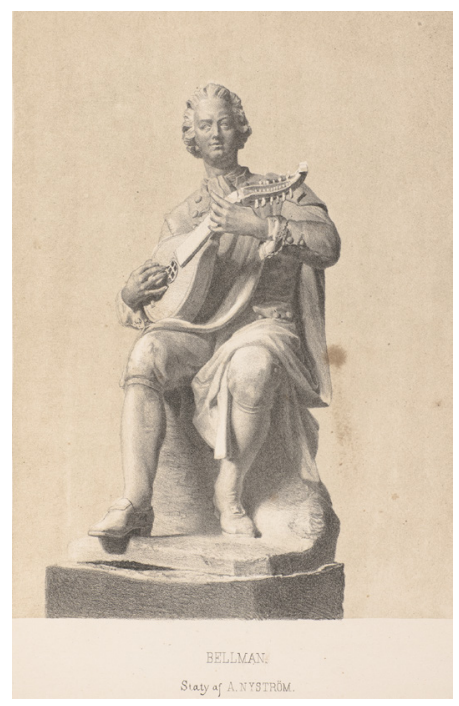

Figure 8. Lithographic depiction of Bellman statue by G. Alfred Nyström, erected in Stockholm I 872. Lithographic Album, I 873. Reproduction: National Library of Sweden/Kungliga biblioteket, Stockholm. License: CC-BY-NC-ND.

cover. Depicted is, however, the fountain initially created by Johan Peter Molin (I8I4-1873) for the Stockholm exhibition in I 866. The white plaster fountain was the centrepiece at the exhibition and was reproduced in several photographic images from the exhibition area. ${ }^{32}$ It later became such a success that national fundraising was initiated to make a bronze version of the statue, which eventually was placed in the public garden Kungsträdgården in central Stockholm. The statue depicts characters from Nordic mythology, such as the water nymph Näcken, the sea giant Ägir, and his wife Ran and their daughters, Kolga, Hrönn, Himingläva, Unn, Duva, Blodughadda, Bylgja, Båra, and Hefring. The statue

32 Johannes Jaeger's photograph of the inaguration of the exhibition, where the fontain is in the centre is alleged to be the first press photograph produced in Sweden. Rolf Söderberg and Pär Rittsel, Den svenska fotografins historia: 1840-1940 (Stockholm: Bonnier Fakta, I983), 85. 


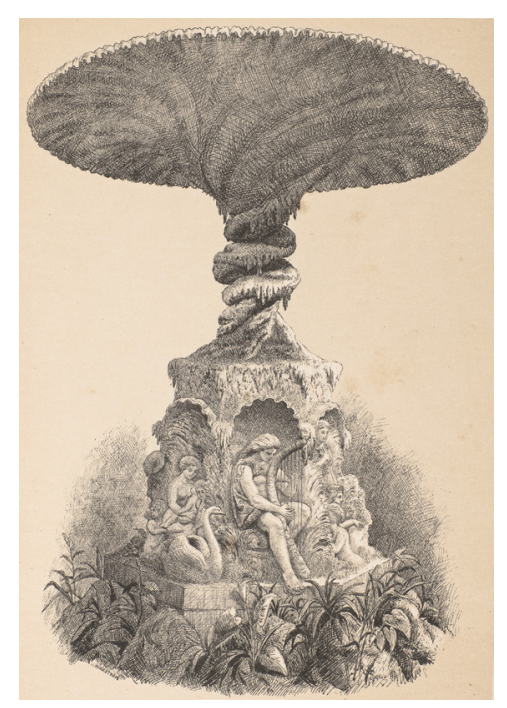

Figure 9. Lithographic depiction of Molin's fountain, erected in Stockholm I 873. In Lithographic Album, I 873. Reproduction: National Library of Sweden/Kungliga biblioteket, Stockholm. License: CC-BY-NC-ND.

was veiled on September 25, I873, most possibly just before the publication of the Lithographic Album. ${ }^{33}$

The text adjoining this reproduction differs from all others in the album. It does not acknowledge the content of the artwork at all, and thus it functions as a relay and not an anchor in relation to the image, using the concepts of Roland Barthes. ${ }^{34}$ Instead, the text argues that some artworks may not be explained in words. The text reads:

There are artworks whose poetical content can hardly be reproduced, artworks in which the brush and the chisel express thought, which the eye more easily may apprehend than the pencil may illustrate. And among these phenomena, Molin's fountain is one which

33 Adverts for the Lithograbic Album appeared in the daily papers in December 1873. See Blekingeposten December 16, I873; Kalmar December 19, I873; Barometern December 23, I873.

34 Roland Barthes, "Rhetoric of the Image," in Image, Music, Text (London: Fontana Press, I977 [1964]), 40-4I. 
has to be seen to be perceived. A description of it would never be able to reproduce the right and original idea of this masterpiece. We limit ourselves therefore to exhibit this plate of the fountain, but eagerly invite every admirer of our melancholy stories about Ägir and his daughters, every lover of the in seaweed-covered "Näckens polka," to with their own eyes behold these romantic fairytale creatures rendered in bronze with poetic warmth. ${ }^{35}$

On the one hand, the lack of text beneath the image and the lack of descriptive text about the artist downplays the fact that this is a two-dimensional reproduction via print. Simultaneously, the text extrapolates that no reproduction could do justice to the original artwork. It has to be viewed in real life. This is for some reason not written out in connection to the other reproductions, while one could argue that this holds true for any reproductions of artworks independent of their medium. For one, all colours in the oil paintings have disappeared in the transformation to lithographic prints, as have their magnificent size. Indeed, it could also be argued that a two-dimensional image never could represent a three-dimensional statue. Consequently, this would hold not only for the Molin's statues, but also for the statues of Bellman and the fisher boy depicted in the album.

\section{Transparency, Media Specificity, and Print Culture}

At the time of publication the Lithographic Album certainly had news value. If nothing else, the cover of the album displays a topical news event-the fountain by Johan Peter Molin had been unveiled the same year, shortly after the artist's death. The other

35 The original text reads: "Det finns konstverk, hvilkas poetiska innehåll kritiken har svårt att återgifva; konstverk i hvilka penseln eller mejseln, uttrycka tankar, som ögat lättare uppfattar än pennan kan åskådliggöra med ord. Och ibland dessa företeelser, är Molins fontän ett som måste ses, för att uppfattas. En beskrifning af densamma skulle aldrig kunna återgifva mästerverkets rätta och originela idé. Vi inskränkta oss derföre att hänvisa till vår plansch öfver fontänen; men uppmana ännu ifrigare hvarje beundrare af våra vemodsfulla sagor om Ägir och hans döttrar, hvarje älskare af den tongfulla 'Näckens polska,' att med egna ögon skåda dessa romantiska sagoväsenden återgifna i brons med poetisk värme.” 
paintings and statues reproduced in the album could likewise be considered as news. Four of the oil paintings and one of the sculptures had recently been acquired by Nationalmuseum and were hence incorporated in the Swedish art historical heritage. In addition, the paintings where inscribed, through the suggested interpretations in the adjoining texts, in contemporary political and ideological debates and thus transformed into relevant societal and political issues. Thus the texts raised the value of the artworks beyond their artistic or aesthetic value and hence the album can be said to mix art, news, and political and ideological issues of the day.

There are two understandings of transparency with regard to art and visual expressions in the album. For one, the interpretations and suggestions on how the images should be understood in the adjoining text do not acknowledge that the images are reproductions. First, the reproductive technique of lithography and its inherent media-specific features are not spelled out. Second, the two-dimensional representations are rather treated as they are real events and individuals. The anachronism is particularly poignant in the case of Winge's painting, which is taken as evidence that men endured pain and hardship much better in the Viking Age than in the nineteenth century. It appears as the oil paintings are apprehended as transparent containers of content. The fact that they are painted by a certain individual, in a certain period and geographical place, and that these paintings in turn have been reproduced through the technique of lithography is not spelled out and acknowledged. This focus on the story and downplay of the artist's work or style can be described as an expression of a photographic paradigm. Put differently, it displays a kind of photographic belief in the images. This, in turn, also implies that these artworks do not need to be viewed in reality and that their media-specific features do not have to be accounted for. Their main purpose is, on the contrary, to convey a visual message, mainly of inducing the right feelings and beliefs in the audience.

Secondly, the adjoining text of Molin's fountain displays another notion of transparency. In this case, the text urges the readers to see the fountain with their own eyes. Underlying this emphasis lies an idea of aesthetic experience, which cannot be 
reached through reproductions. The artwork has to be seen in real life, without any intermediaries, or its value cannot be perceived. Accordingly, this kind of artwork is not presented as a conveyer for a certain ideological, political topic or issue, but should be perceived as a media-specific aesthetic object. Yet this sculpture is a very time-typical expression of national romanticism with its characters from Nordic folklore. However, this single artwork in the album portends the notion of media specificity that has permeated the discourse on the perception of art in the twentieth century. Although not spelled out, this urge to see the artwork in place and not through a reproduction can be linked to its threedimensional form.

In general, the medium of the original as well as the implications for transforming and representing it in two-dimensional prints is not spelled out in the Lithographic Album. The reader is informed that one original is an oil painting while the other twodimensional images are only labelled "picture" (tavla, stycke). In the case of the photographs, nothing is mentioned on their original technique. The sculptures are, however, presented as sculptures and their material, such as stone and copper, are hinted at in the texts. In the case of Molin's fountain, there was, however, a veritable incentive of studying the sculpture in real life. While the sculptures on Bellman and the fisher boy had a clear "front" and "back," the Molin's fountain had vital ornaments and details all around. To see the fountain, one had to move in a circle around it, which other publications on this statue remedied by including images from four different viewpoints. ${ }^{36}$ Such re-mediations, that is, representations of one medium through another medium, emphasize the spatially determined media specificity of the medium of sculpture. ${ }^{37}$ Despite the fact that the concept of media specificity

${ }^{36}$ Molins fontän i fotografi af Johannes Jaeger (Stockholm, I 866). See also Magnus Bremmer, Konsten att tämja en bild: Fotografiet och läsarens uppmärksambet i I 800-talets Sverige (Lund: Mediehistoriskt arkiv, 20 I 5 ), 87-I39.

37 The term “remediation," suggested by media scholars David Jay Bolter and Richard Grusin, implies that every medium is defined as "that which remediates [...] which appropriates the techniques, forms, and social significance of other media." Jay David Bolter and Richard Grusin, 
is primarily related to later periods, the high modernist art theory and critique of the mid-twentieth century, the interest and sensitivity to the particularity of different artistic mediums emerged much earlier, in art theoretical writings and, as this example evidently displays, in popular discourse on art..$^{38}$

All but one of the adjoining texts in the Lithographic Album present the images as conveyer of a certain issue. Moreover, the texts emphasize that these insights could indeed be "seen" in the images. Thus this publication displays a belief typical of the time that the eye could be trained and edified and thereby used as an important tool for increasing one's knowledge. This held for contemporary scientists as well as for the public at large. In I86I, the Swedish pedagogue and researcher Per Adam Siljeström published an essay on the education of the eye, in which he argued for the importance of exercising one's eyes. He concluded that

If anyone wants to learn to view the beauty in art he must diligently look at beautiful pictures and accustom and sharpen the eye to the right perception of beauty. Collections of paintings, statues etcetera, and in addition nature itself, are schools that one cannot neglect to visit [...]. To read gives only half the knowledge. Primarily it is about seeing what you read about. ${ }^{39}$

Remediation: Understanding New Media (Cambridge: MIT Press, I999), 44-65.

${ }^{38}$ The concept of media specificity was popularized by art critic Clement Greenberg in the mid-twentieth century. See, e.g., his essays "Towards a Newer Laocoön," Partisan Review VII, no. 4 (July/August I940): 296-3 I0, and "Modernist Painting" (I96I) in Voice of America Forum Lectures (Washington: U. S. Information Agency, I965), I05-III. The issue was, however, adressed much earlier by Gotthold Ephraim Lessing in Laocoön, trans. Edward Allen McCormick (Baltimore: Johns Hopkins University Press, I984 [I766]).

39 Per Adam Siljeström, "Ögats uppfostran,” Läsning vid husliga härden (I86I): I70-I80. The original text reads: "Vill någon lära sig att se det sköna i konsten så måste han flitigt se sköna bilder för att vänja och skärpa ögat till en rätt uppfattning af skönhetsdragen. Samlingar af taflor, statyer, o.s.v., och slutligen naturen sjelf äro skolor, som han icke får underlåta att flitigt besöka [...]. Att läsa ger blott half kunskap. Det gäller framför allt att $s e$ vad man läser om.” 
Although this text was published some ten years before, it is clear that the Lithographic Album combines a traditional and more modern view on what visual art might bring and how it should be perceived. It ties into the more traditional views on art as conveyer of edifying contents. Moreover, it displays some awareness of the medium of the artwork. This holds true for the oil paintings and sculptures, but not for the photographs and the reproductive techniques of lithography. From a media-historical perspective, it is evident that the Lithographic Album seeks to provide immediacy, which has tinged many later media, like film, television, and virtual reality, particularly in their introductory phase. What is furthermore interesting from a media-historical perspective is that a photographic paradigm colours this album in its ambition to convey stories and experiences visually, and this is done irrespective of medium used. This album thus displays mediations of different media before the advent of media specificity, which prevailed in the twentieth century.

\section{References}

Barthes, Roland. "Rhetoric of the Image." In Image, Music, Text. Translated by Stephen Heath. London: Fontana Press, I977 [I964].

Belting, Hans. Art History after Modernism. Chicago: University of Chicago Press, 2003.

Bjurström, Per. Gamla grafiska blad. Västerås: ICA-förlaget, I974.

Bolter, Jay David, and Richard Grusin. Remediation: Understanding New Media. Cambridge: MIT Press, I999.

Bremmer, Magnus. Konsten att tämja en bild: Fotografiet och läsarens uppmärksambet i 1800 -talets Sverige. Lund: Mediehistoriskt arkiv, 2015 .

Cartier-Bresson, Henri. The Decisive Moment. New York: Simon and Schuster, 1952.

Dahlgren, Anna. Ett medium för visuell bildning: Kulturhistoriska perspektiv på fotoalbum I850-I950. Stockholm: Makadam, 2013. 
Ernst, Wolfgang. "Let There Be Irony: Cultural History and Media Archeology in Parallel Lines." Art History 28:5 (2005): 582-603.

Gaehtgens, Thomas W., and Louis Marchesano. Display and Art History: The Düsseldorf Gallery and Its Catalogue. Los Angeles: Getty Research Institute, 20 I I.

Gitelman, Lisa, and Geoffrey B. Pingree, eds. New Media, I740I9I 5. Cambridge: MIT Press, 2003.

Greenberg, Clement. "Modernist Painting." In Voice of America Forum Lectures. Washington: U. S. Information Agency, 1965.

Greenberg, Clement. “Towards a Newer Laocoön.” Partisan Review VII, no. 4 (July/August, I940): 296-3 Io.

Hamilton, Peter, and Roger Hargreaves. The Beautiful and the Damned: The Creation of Identity in Nineteenth Century Photography. London, National Portrait Gallery, 200I.

Harvard, Jonas, and Patrik Lundell, eds. I80o-talets mediesystem. Stockholm: Kungliga biblioteket, 20 Iо.

Hepp, Andreas. Cultures of Mediatization. Cambridge: Polity, 20 I 2.

Hjarvard, Stig. The Mediatization of Culture and Society. London: Routledge, 20I3.

Huhtamo, Erkki, and Jussi Parikka, eds. Media Archaeology: Approaches, Applications, and Implications. Berkley and Los Angeles: University of California Press, 20I I.

Jenkins, Henry. Convergence Culture: Where Old and New Media Collide. New York: New York University Press, 2006.

Karlholm, Dan. Art of Illusion: The Representation of Art History in Nineteenth-century Germany and Beyond. Bern: Peter Lang, 2004.

Lessing, Gotthold Ephraim. Laocoön. Translated by Edward Allen McCormick. Baltimore: Johns Hopkins University Press, I984 [I766].

Litografiskt album: Portfölj för salongsbordet, Stockholm Artistiska Litografiska Anstalt. Stockholm: J. W. Svenssons Boktryckeri, I873.

Lund, Hans. Intermedialitet: Ord, bild och ton i samspel. Lund: Studentlitteratur, 2002. 
Lundby, Knut, ed. Mediatization of Communication. Berlin: De Gruyter Mouton, 20I4.

Manghani, Sunil. Image Studies. London: Routledge, 20I3.

Medelius, Hans, Bengt Nyström, and Elisabet Stavenow-Hidemark. Nordiska museet under I 25 år. Stockholm: Nordiska museets förlag, I998.

Molins fontän i fotografi af Johannes Jaeger. Stockholm: I 866.

Moxey, Keith. "Visual Studies and the Iconic Turn." Journal of Visual Culture 7:2 (2008): I3 I-I46.

Mussell, James. The Nineteenth-Century Press in the Digital Age. Basingstoke: Palgrave Macmillan, 20 I 2.

Schwartz, Vanessa R., and Jeannene M. Przyblyski, eds. The Nineteenth-century Visual Culture Reader. New York: Routledge, 2004 .

Siljeström, Per Adam. “Ögats uppfostran,” Läsning vid husliga härden (I86I): I70-I80.

Söderberg, Rolf, and Pär Rittsel. Den svenska fotografins historia: I840-I940. Stockholm: Bonnier Fakta, I983.

Söderlind, Solfrid. Porträttbruk i Sverige I 840-I 865: En funktions- och interaktionsstudie. Stockholm: Carlsson, I993.

Turner, Jane, ed. The Dictionary of Art. London: MacMillan Publishers Ltd, I996.

Ward, Gerald W. R. The Grove Encyclopedia of Materials and Techniques in Art. Oxford: Oxford University Press, 2008.

Wilke, Jürgen. "Art: Multiplied Mediatization." In Mediatization of Communication, edited by Knut Lundby, 465-482. Berlin: De Gruyter Mouton, 20I4. 
